\title{
EESTI KEELTEST RAHVALOENDUSTEL
}

\section{KADRI KOREINIK, TÕNU TENDER}

\begin{abstract}
Annotatsioon. Artikkel vaatleb keelte kajastamise tendentse rahvaloendustel: milliseid keeli nüüdis-Eestis osatakse ja millised muutused on aja jooksul keeleoskuses toimunud. Samuti on esitatud järeldusi murdekeele oskuse kohta 2011. aasta rahvaloenduse põhjal. Oluline osa murdekeele mõistjatest elab väljaspool traditsioonilisi murdealasid. Rahvaloenduste tulemused näitavad, et inglise keele oskajate osakaal on kolmveerandsaja aastaga kasvanud 20 korda. Saksa keele oskajate hulk on tänaseni suhteliselt stabiilsena püsinud. Soome keele oskajaid leidub Eestis nüüdseks enam kui saksa keele oskajaid. Artiklis tutvustame Carol Bensoni ja Kimmo Kosoneni (2012) termineid domineeriv keel ehk dominantkeel ja mittedomineeriv keel.
\end{abstract}

Võtmesõnad: rahvaloendus, mitmekeelsus, võõrkeel, murdekeel (kohamurre), Eesti

\section{Sissejuhatus}

Tänaseni on Eestis domineerinud rahvusliku ärkamise ajal tekkinud arusaam, et rahva (rahvuse) määrab ära keel. ${ }^{1}$ Väidet kinnitab eesti keele käsitlemine seadusloomes: eesti keel on eesti identiteedi kandja ja Eesti (ainus) riigikeel (Eesti Vabariigi põhiseadus 1992; Keeleseadus 1995, 2011), Eesti Vabariik peab ,tagama eesti rahvuse, keele ja kultuuri säilimise läbi aegade" (põhiseaduse preambul). (Siiner jt 2008: 212) Eesti kehtiva keeleseaduse esmane eesmärk on ,,arendada, säilitada ja kaitsta eesti keelt ning tagada eesti keele kasutamine peamise suhtluskeelena kõikides

1 Carl Robert Jakobson rõhutas oma esimeses isamaa kõnes: „Pääasi aga, kust ühe rahva vaimuharimise järge äratunnukse, on temal keel. Keel on ühe rahva harimise kandja, ja seepärast ka tema kauni korra ja priiuse sünnitaja, on tema kõige kallim pärandus. Keel on kes üht rahvast rahvaks teeb; ta varjab üht lõpmata väge ja pühaust oma sees. Keel ja mõistus käivad käsikäes, sest keel on avalikuks saanud mõistus. Seepärast võime ka sest, kuidas ühe rahva keel haritud on, kõige paremine rahva enese vaimujärge äratunda.” (Jakobson 1868) 
avaliku elu valdkondades" (Keeleseadus 2011: § 1). Samas on arendatav, säilitatav ja kaitstav valdkond laienenud: keeleseadusega tähtsustatakse eesti riigikeele ja viipekeele järel eesti keele piirkondlikke erikujusid ehk murdeid (Keeleseadus 2011: $\S 3 \lg 3$ ): ,Riik toetab eesti keele piirkondlike erikujude (edaspidi murdekeel) kaitset, kasutamist ja arendamist." Kuigi Eesti seadused kaitsevad peamiselt eesti keelt, on kõik maailma keeled nii suure kui ka väikese kasutajaskonnaga keeled ja murded - väärtuslikud ja olulised, sest on ajaloo vältel talletanud endasse tarkusi ja kujundanud identiteete (nt Nabhan 2001: 151; Skuttnabb-Kangas 2002: 13-14).

Vaatleme artiklis keeleoskuse kajastamist rahvaloendustel: milliseid keeli on registreeritud, kas ja kuidas on hinnatud Eestis keeleoskust, mitmekeelsust ${ }^{2}$ - milliseid (võõr)keeli ${ }^{3}$ on tähtsustatud ja osatakse. Kas suure kõnelejaskonnaga keelte kõrval väärtustatakse ja osatakse ka murdeid? Millised on keeleoskuse suundumused ühiskonna tasandil? Rahvaloendus tugineb keeleoskuse kajastamisel inimeste enesehinnangule, kuid keelte oskamise mõõtmine, st keeleoskustasemete täpne määramine ei ole siinse kirjutise eesmärk. Mõnel juhul kasutame rahvaloenduse andmete tõlgendamiseks teiste uurimuste tulemusi. Püüame vastata kahele küsimusele: 1) milline on Eesti elanike keeleoskus ja kuidas see on aja jooksul muutunud; 2) mida võime järeldada murdekeele oskuse kohta 2011. a rahvaloenduse põhjal.

Ühiskonna keelelist mitmekesisust mõjutavad kaudselt muutuvad keelehierarhiad: milliste keelte oskust peetakse oluliseks, prestiižseks; milliseid keeli õpetatakse haridussüsteemis ning millises järjekorras; millised keeled on ilmunud keelemaastikele (ingl linguistic landscapes) ${ }^{4}$.

2 Tihti eristatakse isiku mitme võõrkeele oskust, st isiku mitmekeelsust ehk paljukeelsust (ingl plurilingualism) ning ühiskonna mitmekeelsust (ingl multilingualism), s.o mitme keele oskamist või mitme keele kooseksisteerimist ühiskonnas (Raamdokument 2007: 20), vrd ka Dulitšenko 2004: 26.

3 Võõrkeel on õpipsühholoogia põhimõtte kohaselt iga keel peale kõneleja emakeele ja/või esimese keele. Keeleseaduse (2011: § 5) mõttes on võõrkeel iga keel peale eesti keele ja eesti viipekeele; võõrkeeleks peetakse ka vähemusrahvuse keeli, mida vähemusrahvusest Eesti kodanikud on Eestis põliselt kasutanud emakeelena. Kui 1934. a keeleseaduses olid võorkeel (1934. a võõras keel) ja vähemusrahvuse keel sama tasandi terminid, siis nii 1995. kui ka 2011. a keeleseaduses on vähemusrahvuse keel võõrkeele alaliik (Tender 2008: 158).

4 Avalikus ruumis eri eesmärkidel kuvatud (eksponeeritud) sõnad ja kujutised (Shohamy, Gorter 2009). 
Keelehierarhiaid mõjutab poliitika - tahtlik või tahtmatu, avaliku(m) või varjatu(m) praktika -, aga ka ettekujutused keeltest, st keeleideoloogia, mis (taas)loob sotsiaalseid erinevusi (Blackledge 2005). Keelehierarhiate tipus on enamasti riigi elanike enamiku standarditud ehk normikeel või lingua franca'(d), teises otsas enamasti standardimata ehk normimata keelekujud, väikese osa inimeste poolt kasutatud, (sotsiaalselt) madalama staatusega keelepraktika ${ }^{5}$. Madalast või ambivalentsest positsioonist hoolimata leidub mõnel pool Eestiski nn jäänukalasid (ingl residual spaces), kus ühist identiteeti ja riiklikku ühtsust loovad tegevused (haridussüsteem, meedia, keelestandard ehk normikeel) on olnud nõrg(em)ad ja/või vaidlustatud (vrd Appadurai 2005: 190). Nõnda on mitmel pool Eestiski alal püsinud murdekeel (kohamurre). Rahvaloenduse tulemustele toetudes analüüsime sedagi, milliseid normikeelest (kirjakeelest) erinevaid kohalikke keelekujusid, murdeid ja murrakuid Eestis osatakse.

Ühiskonna keelerikkust mõjutav otsene, ent samuti poliitikast mõjutatud tegur on inimeste ränne. Nõukogude perioodil oli Eesti sisserändemaa, mis alates 1990. aastatest muutus väljarändemaaks, kust esmajoones venelased ja teised endise Nõukogude Liidu rahvad rändasid tagasi oma kodumaale. ${ }^{6}$ Lääne-Euroopasse emigreeruti tollal suhteliselt tagasihoidlikult, erandiks oli naabermaa Soome (Anniste jt 2012). Juba aastakümme hiljem olukord muutus. Euroopa Liiduga (EL) ühinemine 2004. aastal, eriti aga 2006. aasta, mil mitu ELi riiki avas oma tööturu liidu uusliikmetele, vähendas oluliselt väljarände piiranguid. Majanduslanguse ajal süvenes Eesti elanike väljaränne läände veelgi ${ }^{7}$. Eestlaste varasemad suuremad väljarändelained toimusid XIX sajandi keskpaigast kuni esimese maailmasõjani, mil demograafilise plahvatuse tagajärjel asuti Vene impeeriumi aladele, ning teise maailmasõja ajal, mil põgeneti läände. Väljarändele võib järgneda teatud tingimustel ka tagasiränne (vt Tammaru jt 2010; Pungas jt 2012). Tagasipöördujate keeleoskus ja teiste keeltega seotud kogemused on muutunud.

5 Kuigi praktika teooriaid on mitu, peame praktika mõiste all Pierre Bourdieu (1977, 2003) eeskujul silmas harjumuspärast (ka rutiinset) tegevust või inimese teadvuses reflekteerimata käitumismustreid. Keelepraktika on igapäevane keelekasutusviis, see, kuidas (ja ka millest) räägitakse.

6 Taasiseseisvunud Eesti suure väljarände põhjusena on nimetatud nõukogudeaegset suurt sisserännet (Anniste, Tammaru 2014).

7 Väljarännanud Eesti elanikest moodustasid 1/3 mitte-eestlased ning 2/3 eestlased. 


\section{Rahvaloenduse ideoloogiline ja poliitiline mõõde}

Enamik rahvaloenduste küsimustikke sisaldab inimeste loendamise kõrval küsimusi subjektiivselt hinnatava identiteedi aspektide (rass, rahvus/etnos, keel) kohta. Seetõttu võib rahvaloendust pidada poliitiliseks ja identiteeti konstrueerivaks nähtuseks (nt Kertzer, Arel 2004). Samas on sotsiaalselt konstrueeritud etniline vm kollektiivne identiteet oma tagajärgedes ülimalt reaalne - keelepraktika võib lähtuda või olla mõjutatud nendest identiteetidest. Poliitilisus seisneb selles, et identiteedi- ja keelekategooriate valik tehakse loendusel etteantud, poliitiliselt motiveeritud kategooriate seast.

Nüüdis-Eestis ei leidu ilmselt palju inimesi, kes kahtleks rahvaloenduse tähtsuses riikliku poliitika (nt haridus) planeerimisel või teabe kogumise vajaduses. Ent rahvaloendus toetab ka vaatenurka, et inimpopulatsioone saab rühmitada selgelt piiritletud kategooriate abil ning loob nõnda reaalsusest paratamatult moonutatud pildi (Kertzer, Arel 2004; vt ka Anderson 1991; Scott 1998; Appadurai 2006). Loenduskategooriad või väärtusklassid ,püsielanik”, „rahvus” ja „keel” ei ole neutraalsed ega tulene sageli konkreetsetest vajadustest, vaid on eri huvidega pooli hõlmava poliitilise protsessi tulemus (ingl pre-census politics; Dave 2004), mida on omakorda kujundanud minevik ja riiklikud huvid (Arel 2002b; Tisliar 2013). Euroopas ja Uues Maailmas hakati loendustel keeleküsimusi esitama XIX sajandi keskel (Arel 2002b: 94). Peamiselt on esitatud kolme liiki keeleküsimusi: lapsena õpitud esimese keele, enim kasutatava keele ja riigikeele oskuse kohta. Sealjuures on emakeele küsimus rahvaloendustel toiminud n-ö tagasivaatelisena, tähistades eelkõige nii indiviidi rahvuslikku identiteeti kui ka sõna otseses mõttes ema keele kasutust, vähem indiviidi igapäevast keelekasutust (Arel 2002b: 97, 109). Lääneriikide rahvaloenduste põhiprobleem on aastakümneid olnud rände ja loenduse konfidentsiaalsuse teemad, endise idabloki maades ja Venemaal on fookuses olnud peamiselt rahvus- ja keeleküsimused (Arel 2002a: 823).

Viimase Eesti rahvaloenduse puhul on selle poliitilistele ja ideoloogilistele aspektidele viidanud etnoloog Indrek Jääts (2013). 2011. aastal võimaldas rahvaloendus esimest korda Eesti rahvaloenduste ajaloos Eesti püsielanikel hinnata ja märkida loendusankeeti oma eesti murrete oskust. Jääts $(2013:$ 1076, 1107) väidab, et setu ja võru aktivistid kasutasid viimast rahvaloendust osaliselt enda huvides ära. Meie arvates kuulub aktivistide tegevus ootuspärase demokraatliku poliitikategemise juurde ning uute väärtusklasside ,leiutamine” pole kaugeltki vaid Eestile iseloomulik. 
Kõikjal on rahvaloenduse küsimuste ja kategooriate formuleerimine poliitikaga põimunud: kui mõned loendusküsimused ja -kategooriad on neutraalsed ja loomulikud, siis teised on loendustesse arvatud poliitilise surve tulemusena (vt Kertzer, Arel 2004: 15). Jääts (2013: 1091) rõhutab murdeküsimuse raskesti mõistetavust (mitmetähenduslikkust) ning tõstab esile etnoregionalistide propaganda võimalikku mõju loenduse tulemustele (valiidsusele). Tõepoolest, rahvaloendustel püütakse üldjuhul vältida suure tõlgendusruumiga küsimusi, ometi on keeleküsimusi mitmel pool tõlgendatud pigem etnilist kuuluvust või rahvuslikku identiteeti kui keeleoskust ja -kasutust mõõtva küsimusena. Pavol Tisliar (2013) näeb seost esimeste ja järgnevate loenduste kontseptsioonide ja küsimuste vahel. Tema näitel oli keel Austria-Ungari keisririigis alates 1880. a rahvaloendusest kasutusel rahvuse indikaatorina, ent n-ö kontseptuaalne inerts toimis pärast riigi lagunemistki. Ka nõukogudeaegsetes loenduste instruktsioonides ei suudetud selgeks teha, kuidas tuleks tõlgendada emakeele küsimust: kas esimese, lapsepõlves õpitud keelena, nagu soovitas ÜRO, või keelena, mida inimesed eelistavad iga päev kasutada. 1990. aastate sotsioloogilised uuringud näitasid, et paljud pidasid silmas koguni kolmandat võimalust, st rahvus- ja riigikeelt (Arel 2002a: 820). Meie hinnangul ei pruugi loenduse küsimus emakeele kohta kõikide etniliste rühmade puhul anda võrreldavaid, keelekasutust peegeldavaid tulemusi. Näiteks valgevene keel emakeelena ei näita tõenäoliselt selle igapäevast kasutamist, samas eesti keel näitab. Rahvuse ja emakeele küsimused on suure tõlgendusruumiga ning nende kohta küsimine on tänases hilismodernses ja üleilmastunud ühiskonnas, eriti mitmekeelsete ja -rahvuseliste perede ning rände sihtmaade puhul problemaatiline.

\section{Eesti rahvaloenduste ajaloost}

Rahvaloenduste-eelset rahvaarvu on enamasti hinnatud kaudsete meetoditega, st eri allikaid - kirikuraamatuid, adramaa- ja hingerevisjone kombineerides (Tiit 2011a). Ajaloolise demograafia kõige tähtsam allikmaterjal on kiriku meetrikaraamatud, mille süstemaatiline pidamine algas Euroopas XVI sajandil ja Eestis tulenevalt Rootsi kirikuseadusest XVII sajandi lõpul (Must 2000). Üksikutes kogudustes hakati sünde, abiellumisi ja surmi registreerima juba XVII sajandi esimesel poolel, nt Keilas 1627. Juba XVI sajandil alustati adramaarevisjone, kus peeti mõningast arvet 
ka tööjõuliste inimeste üle. XVIII sajandi alguses hakati Vene impeeriumis korraldama maksukohustuslaste kindlakstegemiseks hingeloendusi; Balti kubermangude kohta hakkas revisjonikohustus kehtima neljanda hingeloendusega 1782. aastal (Vahtre 1973). 1860. aastal alustati Eestija Liivimaa rüütelkonna initsiatiivil rahvaloenduse ettevalmistusi, mis päädisid prooviloendustega 1864. aastal Jäneda mõisas, 1866. aastal Rae ja Lagedi mõisas, 1867. aastal Liivimaa ja 1868. aastal Eestimaa linnades, kuid rahvaloendus lükkus ikalduse tõttu edasi (E. Tannberg, T. Tannberg 1989; vrd Tiit 2011b).

Esimeseks Eesti maa-ala hõlmavaks rahvaloenduseks on peetud 1881. aastal Tsaari-Venemaa koosseisu kuulunud Eestimaa ja Liivimaa kubermangu statistikakomitee korraldatud loendust. Tol korral jäi loendusest välja nt Narva, mis kuulus Peterburi kubermangu koosseisu. Eesti alal elas toona 893558 inimest (Selirand, Siilivask 1996: 250; Raag 2008: 78) ${ }^{8}$. Nimetatud rahvaloenduse andmed annavad teavet Eesti ala rahvastiku vanuse, soo, perekonnaseisu, usutunnistuse, rahvuse, keele, kirjaoskuse, ameti, teenistus-, elu- ja sünnikoha ning vaimsete ja füüsiliste puuete kohta. Toonasel rahvaloendusel koostati isiku- ja majakaardid (= leibkonna ankeet). Viimasele märgiti, kas isik on eestlane, sakslane, venelane, lätlane, juut (või kes muulane?) ja milline on tema räägitav keel (eesti, saksa, vene, läti, juudi või mis keel?) (Must 2000: 164). Eesti keele kõnelejaid oli maal ja linnades kokku ligi 90\% elanikkonnast, saksa keele kõnelejaid u 5\%, vene keele kõnelejaid u 3\% ning ülejäänud olid muude keelte kõnelejad (Raag 2008: 78; Tiit 2011a: 19).

Esimene ja ainus kogu Tsaari-Venemaad hõlmav rahvaloendus korraldati 1897. aastal. Loenduslehed koostati majapidamiste kaupa, küsiti mh emakeelt (ema keel) (Must 2000: 167). Eesti alal elas kokku 986373 inimest ${ }^{9}$, neist u 90\% kõnelesid emakeelena eesti keelt; üle 4\% vene keelt; 3,6\% saksa keelt; $1,0 \%$ läti keelt; $0,6 \%$ rootsi keelt; $0,5 \%$ jidišit; $0,3 \%$ poola keelt, vähemal hulgal leidus ka muude keelte kõnelejaid (vrd Selirand, Siilivask 1996: 252-253; Raag 2008: 113-114).

Iseseisvas Eesti Vabariigis korraldas Riigi Statistika Keskbüroo rahvaloenduse 1922. ja 1934. aastal. 1922. aastal hõlmas loendus ka elumaju ja kortereid. 1922. a loenduse järgi elas riigis 1107059 elanikku (Rahva-

8 Ilma Narva ja Valga linna arvestamata elas Eestis 881455 inimest (Tiit 2011a: 18).

9 Selgi korral jäi Eesti andmetest välja Narva linn. Vrd Ene-Margit Tiidu andmed (2011a: 23): Eesti territooriumil elas loenduse andmetel 958351 inimest. 
loendus 1922: 9). Eestlasi oli 969976 (87,7\%), neist 8595 inimesele $(0,8 \%)$ ei olnud eesti keel harilik keel (rahvaloenduse küsimus: Mis keelt harilikult eraelus kõneleb?); venelasi oli 91109 (8,2\%); sakslasi 18319 $(1,7 \%)$; juute $4566(0,4 \%)$; rootslasi $7850(0,7 \%)$; muid $14508(1,3 \%)$. Rahvus oli teadmata 731 inimese (0,1\%) puhul (Rahvaloendus 1922: 31). Võõrkeelte oskuse kohta küsimusi ei esitatud.

1934. aasta loenduse küsimustik sarnanes põhiosas 1922. aasta küsimustikuga. Esimest korda fikseeriti Eesti elanike võõrkeelte oskus 1934. a rahvaloendusel. Küsiti keeli, mida isik kõneleb tavakeelena (pr langue habituelle) ${ }^{10}$ ning keelteoskust peale tavakeele ( $\mathrm{pr}$ exceptée la langue habituelle) (Rahvastiku koostis 1934: 104-117). Tavakeelena pandi kirja eesti, vene, saksa, rootsi, läti, juudi, ingeri, mustlase, soome, poola, inglise, tatari, heebrea, prantsuse, taani, leedu, türgi, tšehhi, itaalia, hollandi keel, lisaks võis nimetada mõne muu keele ning nende oskajad (Rahvastiku koostis 1934: 104-109). Kirja pandi ka keeled (ja nende oskajad), mida osati peale tavakeele (st võõrkeelena): eesti, vene, saksa, inglise, läti, prantsuse, soome, rootsi, poola, (tehiskeel) esperanto, juudi, ladina, itaalia, heebrea, taani, leedu, hispaania, ingeri, norra, mustlase, kreeka, tšehhi, portugali, hollandi, ungari, ukraina, türgi, tatari, hiina, rumeenia, serbia, bulgaaria, flaami, jaapani, gruusia, armeenia, pärsia, isuri, kirgiisi, araabia, liivi keel ja muud keeled (Rahvastiku koostis 1934: 110-117).

1941. aastal korraldasid Saksa okupatsioonivõimud seitsmest küsimusest koosneva loendusprogrammi alusel rahvastiku arvestuse (Tiit 2011a: 45-46). Eesti rahvaarv oli 1017475 inimest, eestlaste osatähtsus oli 90\% (Tiit 2011a: 47). Elanike keeleoskuse kohta küsimusi ei esitatud.

Pärast teist maailmasõda korraldati Eestis kogu Nõukogude Liitu hõlmanud rahvaloenduste raames neli loendust: 1959., 1970., 1979. ja 1989. aastal. Neil loendustel esitatud küsimused olid põhiosas sarnased. Neist kolmel viimasel loendusel küsiti peale emakeele mõnda NSV Liidu rahvaste keelt, mida isik vabalt valdas, kusjuures vaba valdamise all peeti silmas oskust selles keeles lugeda, kirjutada ja vabalt kõnelda või ainult vabalt kõnelda. Lubatud oli märkida ainult üks NSV Liidu rahvaste keel see, mida isik kõige paremini valdas.

2000. aasta loendus oli taasiseseisvunud Eestis esimene. Eestis elas 1370052 alalist elanikku, neist 67,9\% olid eestlased (Rahvaloendus

${ }^{10}$ Lähedane tänapäeval kasutatavale kodukeele mõistele. 
2000). Loendusküsimustiku väljatöötamisel arvestati rahvusvahelisi soovitusi ning rahvaloenduse andmed on põhiosas võrreldavad teiste riikide loendusandmetega. Sellel rahvaloendusel küsiti vastaja emakeelt (eesti, vene, ukraina, valgevene, soome, läti, muu keel (kirjutada)), lisaks ka emakeelest erinevat keelt (Milliseid keeli te veel oskate?), mida isik oskab lugeda, kirjutada või kõnelda. Keeleoskuse nõuded olid võrreldes Nõukogude aja loendustega suhteliselt väikesed. Võõrkeele oskuse küsimusele vastamine oli vabatahtlik, ${ }^{11}$ seetõttu jättis $14,2 \%$ elanikest sellele vastamata. Küsimus esitati kõigi elanike, sh väikelaste kohta. Võõrkeeleks arvati iga emakeelest erinev keel, sh ka oma rahvuse keel, kui see polnud isiku emakeel. Etteantud vastusevariandid olid: eesti keel, vene keel, inglise keel, saksa keel, prantsuse keel, soome keel, rootsi keel, läti keel, oma rahvuse keel, muu(d) keel(ed) ja ei oska (Rahvaloendus 2000, isikulehe küsimus 14). Ilmnes, et $68,2 \%$ eestlastest oskas vene keelt, $35,2 \%$ inglise keelt, $16,6 \%$ soome keelt ja 14,9\% saksa keelt. Venelastest oskas 44,5\% eesti keelt, 17,4\% inglise keelt, 5,4\% saksa keelt, 1,6\% soome keelt. Küsimusele vastanutest $72 \%$ oskas vähemalt üht võõrkeelt ning $28 \%$ ei osanud peale emakeele ühtegi muud keelt. Kõige rohkem osati vene keelt (49\% vastanutest) ja inglise keelt (29\% vastanutest), järgnes eesti keel, seda oskas $45 \%$ vastanud mitte-eestlastest.

Seni viimane Eesti rahvaloendus toimus 2011. aastal. Eestis elas 1294455 inimest, neist 902547 eestlast $(69,7 \%), 326235$ venelast $(25,2 \%), 64038$ muu rahvuse esindajat (5\%) ning rahvus oli teadmata 1635 inimese $(0,1 \%)$ puhul. Traditsiooniliselt küsiti emakeele kohta (Mis on Teie emakeel?). Vastusevariandid olid: eesti, vene, ukraina, soome, inglise, muu keel (MÄRKIGE). Isikuankeedis küsiti esimest korda, kas inimene oskab mõnda kohalikku keelekuju, murret või murrakut, ja paluti nimetada see kohalik keelekuju, murre või murrak, mida osatakse (kõige paremini). Sooviti teada sedagi, kas loendatav oskab peale emakeele veel mõnda keelt ning paluti nimetada oskuse järjekorras need emakeelest erinevad keeled, mida inimene oskab (Kas Te oskate peale

\footnotetext{
${ }^{11}$ Vastamise vabatahtlikkus oli tingitud juriidilistest põhjustest: rahvaloenduse seadus võeti vastu 1998. aastal ning selle kohaselt oli kohustuslike küsimuste hulka võetud vaid küsimus eesti keele oskuse kohta. Pärast 1998. aasta prooviloendust otsustati eesti keele oskuse küsimus asendada võõrkeele oskuse küsimusega, kuid seadust enam muutma ei hakatud ja seetõttu ei olnud inimestel kohustust küsimusele vastata.
} 
emakeele veel mõnda keelt? Palun nimetage oskuse järjekorras need emakeelest erinevad keeled, mida Te oskate (alustage keelest, mida Te kõige paremini oskate)).

\section{Eesti ühiskonna võõrkeeleoskusest}

Aja jooksul on muutunud võõrkeele mõiste ja keeleoskuse (hindamise) kriteeriumid. Kui XX sajandi esimesel poolel oli võõrkeeleoskus pigem erand, siis tänapäeval peetakse võõrkeelte oskust inimese üheks põhioskuseks. See kajastub ka rahvaloenduste tulemustes. Euroopas ja mujalgi maailmas kasutatavas Euroopa keeleõppe raamdokumendis määratletakse võõrkeeleoskust kui oskust kasutada keeleteadmisi (hääldus, grammatika, sõnavara) eesmärgipäraselt suuliste ja kirjalike tekstide mõistmiseks (kuulamis- ja lugemisoskus) ning koostamiseks (rääkimis- ja kirjutamisoskus), võttes arvesse konteksti ja suhtluspartnereid (Raamdokument 2007). Võõrkeeleoskuse hindamiseks (mõõtmiseks) on kasutusel eri skaalad. Tänapäeval kasutatakse Eestis ja Euroopas võõrkeeleoskuse hindamiseks peamiselt Euroopa Nõukogu keeleoskustasemeid (A1-C2) (vt Raamdokument 2007). Rahvaloendustel esitavad inimesed oma keeleoskuse kohta enesehinnangulised vastused. ${ }^{12}$

Loendustel on inimeste keeleoskuse kohta kogutud eri laadi teavet: keeleoskuse nimetamise võimalused on rahvaloendustel mõnevõrra erinenud. Näiteks Nõukogude ajal 1970., 1979. ja 1989. aastal toimunud loendusel ei küsitud elanikelt kapitalistlikus maailmas kõneldavate keelte oskust, vaid ainult ühe Nõukogude Liidu rahvaste keele valdamist, mida isik kõige paremini oskas. Tabelis 1 kõrvutame Eesti Vabariigi 1934., 2000. ja 2011. aasta rahvaloenduse mõningaid andmeid. 1934. aastal loendati Eestis 1126413 inimest, 2000. aastal 1370052 ja 2011. aastal 1294455 alalist elanikku.

${ }^{12}$ Keeleoskuse kohta annab täpsemat teavet testimine. Paraku on selline uurimisviis kulukas. Euroopa Komisjoni algatusel toimus 2011. aasta veebruaris-märtsis põhiharidust lõpetavate (ISCED2) õpilaste keeleoskust mõõtev Euroopa keeleoskusuuring (ingl European Survey on Language Competences). See korraldati 14 uuringuriigis (16 haridussüsteemis). Uuringu eesmärk oli mõõta, kuivõrd oskavad õpilased võõrkeelt kasutada, et aru saada suulistest ja kirjalikest tekstidest või väljendada end kirjalikult (seega kuulamis-, lugemis- ja kirjutamisosakus). Eestis olid testitavateks keelteks inglise ja saksa keel (Euroopa keeleoskusuuring 2012). 
Tabel 1. Eesti elanike keeleoskus 1934., 2000. ja 2011. ${ }^{13}$ aasta rahvaloenduse andmetel

\begin{tabular}{|l|r|r|r|r|r|r|}
\hline \multirow{2}{*}{ Keel } & \multicolumn{2}{|c|}{1934} & \multicolumn{2}{c|}{$\mathbf{2 0 0 0}$} & \multicolumn{2}{c|}{$\mathbf{2 0 1 1}$} \\
\cline { 2 - 7 } & $\begin{array}{c}\text { Oskajate } \\
\text { arv }\end{array}$ & $\begin{array}{c}\text { Osa- } \\
\text { kaal }\end{array}$ & $\begin{array}{c}\text { Oskajate } \\
\text { arv }\end{array}$ & $\begin{array}{c}\text { Osa- } \\
\text { kaal }\end{array}$ & $\begin{array}{c}\text { Oskajate } \\
\text { arv }\end{array}$ & $\begin{array}{c}\text { Osa- } \\
\text { kaal }\end{array}$ \\
\hline Vene keel & 197015 & 17,5 & 578004 & 42,2 & 545537 & 42,1 \\
\hline Inglise keel & 21793 & 1,9 & 345854 & 25,2 & 495420 & 38,3 \\
\hline Soome keel & 5729 & 0,5 & 138354 & 10,1 & 167314 & 12,9 \\
\hline Saksa keel & 112938 & 10,0 & 140004 & 10,2 & 130191 & 10,1 \\
\hline Prantsuse keel & 13351 & 1,2 & 9912 & 0,7 & 18677 & 1,4 \\
\hline Läti keel & 16753 & 1,5 & 3072 & 0,2 & 2922 & 0,2 \\
\hline Muu(d) keel(ed) & 13164 & 1,2 & 26658 & 1,3 & 58017 & 4,5 \\
\hline Ei oska võõrkeeli ${ }^{14}$ & 851569 & 75,6 & 323950 & 23,6 & 369027 & 28,5 \\
\hline $\begin{array}{l}\text { Teadmata või } \\
\text { ei ole rakendatav }\end{array}$ & 1384 & 0,1 & $194140^{15}$ & 14,2 & $69203^{16}$ & $5,4^{17}$ \\
\hline
\end{tabular}

Vene keele oskajate osakaal oli suhteliselt suur (17,5\%) juba 1934. aastal, kuid 2000. aastaks oli see üle kahe korra kasvanud (42,2\%) ning püsis pea samal tasemel ka 2011. aastal (42,1\%). Saksa keele oskajate osakaal ühiskonnas on kolmveerandsaja aasta jooksul suhteliselt stabiilsena püsinud (u 10\%). ${ }^{18}$ Samas ilmneb, et 2011. aastal leidus Eestis soome keele

13 Tabeli 2011. a veerg on koostatud tabelite RL0431: RAHVASTIK EMAKEELE JA SOO JÄRGI, 31. DETSEMBER 2011 ja RL0436: RAHVASTIK EMAKEELE, VÕÕRKEELTE OSKUSE, SOO JA ELUKOHA JÄRGI, 31. DETSEMBER 2011 põhjal.

14 1934. aasta loendusel märgiti ainult tavakeele oskusega inimesi, st neid, kes ei osanud teisi keeli; levinumad tavakeeled olid eesti keel (1 000035 inimest e 88,8\%); vene keel (91 720 inimest e 8,1\%); saksa keel (18 437 inimest e 1,6\%); rootsi keel (6368 inimest e 0,6\%); läti keel (3511 inimest e 0,3\%); juudi keel (eristati juudi ning heebrea keelt - 2381 inimest e $0,2 \%$ ).

15 2000. aasta rahvaloendusel oli võõrkeele oskuse küsimusele vastamine vabatahtlik, seetõttu jäi sellele küsimusele vastus saamata 194140 inimeselt, neist 102126 (ehk 52,6\%) olid alla 15-aastased lapsed. Tõenäoliselt ei soovitud paljude laste ja vanurite puhul märkida vastust ,ei oska”, vaid jäeti küsimusele lihtsalt vastamata.

${ }^{16}$ Sellest on keeleoskus teadmata 24182 juhul ning ei saa rakendada 45021 juhul (alla kolmeaastased).

${ }^{17}$ Sellest teadmata $1,9 \%$ ja ei saa rakendada $3,5 \%$.

${ }^{18}$ Saksa keele populaarsus on pärast teist maailmasõda nii Eestis kui ka mujal Euroopas vähenenud, samas on saksa keele oskus loenduse andmetel kõige levinum 
oskajaid esimest korda rohkem kui saksa keele oskajaid. Viimane fakt on huvitav seetõttu, et saksa keel on olnud üldhariduses pikka aega esimese või teise valitava võõrkeele valikute seas ${ }^{19}$, kuid soome keel saavutas uues põhikooli riiklikus õppekavas (PRÕK 2011) teise (võimaliku) õpitava võõrkeele staatuse alles mõne aasta eest. ${ }^{20}$ Soome keele (tõenäoliselt suuline) oskus on seotud Eesti elanike tihedate Soome sidemetega, sh Soomes töötamisega; seda on õpitud peamiselt väljaspool formaalharidussüsteemi. ${ }^{21}$ Inglise keele oskajate osakaal on võrreldes 1934. aastaga 20 korda kasvanud. ${ }^{22}$

vanuserühmas 15-29 eluaastat, kus seda nimetas 45593 inimest, ning vanuserühmas 30-49 eluaastat, kus seda nimetas 40311 inimest, vt RL0438: RAHVASTIK VÕÕRKEELTE OSKUSE, VANUSERÜHMA JA ELUKOHA JÄRGI, 31. DETSEMBER 2011.

${ }^{19}$ Riiklike õppekavade järgi on koolidel olnud võimalus õpetada (eesti õppekeelega) põhikoolis esimese ja teise võõrkeelena kas inglise, prantsuse, saksa või vene keelt. Õppekava võimalustest hoolimata õpetatakse põhikooliastmes esimese võõrkeelena peamiselt inglise keelt ning teise võõrkeelena peamiselt vene keelt. Eesti hariduse infosüsteemi (EHIS) andmetel õpiti Eesti üldhariduskoolides peale eesti keele ja ülal nimetatud nelja võõrkeele 2012/13. õppeaastal ka itaalia, rootsi, soome, hiina, hispaania, jaapani, kreeka, ladina, norra, suahiili, heebrea ja taani keelt ning eesti viipekeelt. Kuid neid keeli õpib märksa väiksem hulk õpilasi ning väiksemas mahus.

${ }^{20}$ Uus põhikooli riiklik õppekava (PRÕK 2011) võimaldab õpetada põhikoolis teise võõrkeelena ükskõik millist võõrkeelt, arvestades kooli võimalusi ja õpilaste soove. Õppekava $\S 13$ lg 2 järgi õpetatakse B-võõrkeelena inglise, vene, saksa, prantsuse keelt või muud võõrkeelt. Varem puudus võimalus õpetada muud võõrkeelt B-võõrkeelena. 2013/14. õppeaastal õpetati soome keelt teise võõrkeelena vähemalt kuues Eesti põhikoolis.

${ }^{21}$ Soome keele oskajate arv oli kõige suurem vanuserühmas 30-49 eluaastat (82 362 inimest), vt RL0438: RAHVASTIK VÕÕRKEELTE OSKUSE, VANUSERÜHMA JA ELUKOHA JÄRGI, 31. DETSEMBER 2011.

${ }^{22}$ Eesti ühiskonnas (sh ajakirjanduses) arutati 1920. aastate lõpul - 1930. aastatel küsimust, milline peaks olema esimene õpetatav võõrkeel. Nt riigimees ja ajakirjanik Jaan Tõnisson pidas oluliseks, et koolides õpetatakse esimese võõrkeelena inglise keelt. Samas pidas Tõnisson iseenesest mõistetavaks, et haritud inimesed oskavad vähemalt paari võõrkeelt, sh saksa või vene keelt (vt Tõnisson 1929; Tender 2010: 26). 


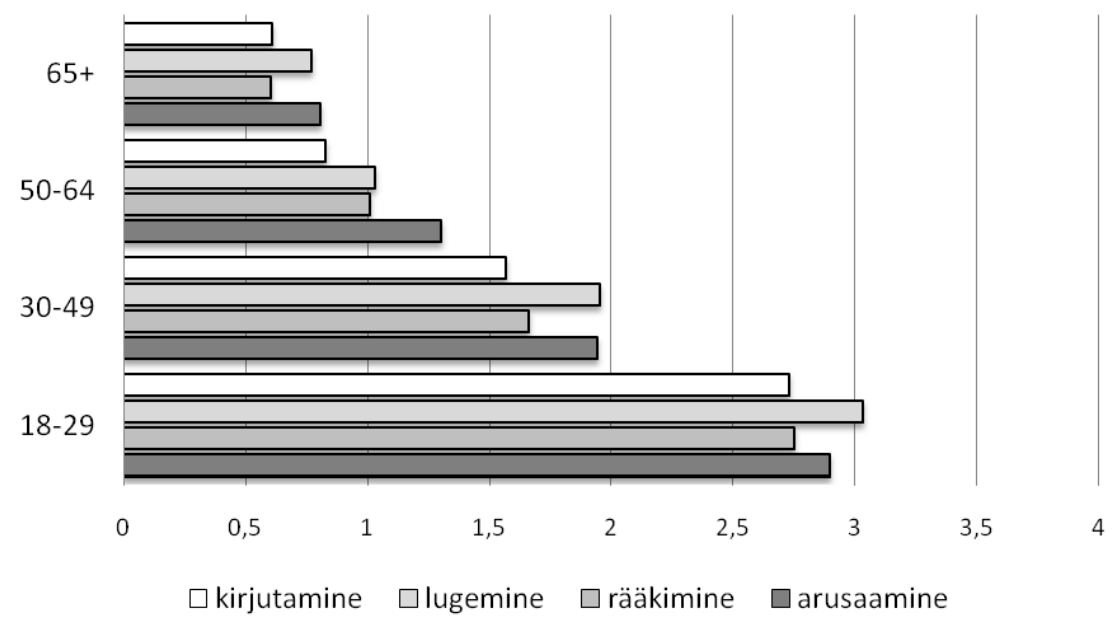

Joonis 1. Inglise keele osaoskuste keskväärtused vanuserühmade kaupa, $\mathrm{N}=285$. Allikas: ELDIA

Nagu juba märkisime, oli rahvaloenduste andmeil võõrkeelte oskus vanuserühmades erinev: 2000. ja 2011. a märkisid nooremad inimesed (eriti vanuserühm 15-29 eluaastat) eelkõige inglise keele oskust. ${ }^{23}$ Vanemates earühmades oli inglise keele oskajate osatähtsus väiksem ning vene keele oskajate osatähtsus suurem. Mitte-eesti emakeelega elanike eesti keele oskus oli eri rühmades üsna sarnane. Ka 2011. aastal Eestis tehtud vanuseliselt ja sooliselt esinduslik postiküsitlus kinnitab erinevat inglise keele oskust (vt joonis 1). Respondentidel paluti märkida iga osaoskuse puhul, kuidas nad seda hindavad. Keele osaoskusi mõõdeti viiepalliskaalal (üldse mitte, halvasti, mõnevõrra, vabalt, hästi). Arvutasime eri vanuserühmade inglise keele osaoskuste aritmeetilised keskmised. Dispersioonianalüüsiga tegime kindlaks, et vanuserühmade osaoskuste hinnangute väärtuste hajuvust ei saa seletada valimi üldise hajuvusega ja vanuserühmade hinnangutes on statistiliselt olulised $(\mathrm{p}=0,05)^{24}$ erinevused.

\footnotetext{
${ }^{23}$ Vanuserühm 30-49 eluaastat oskab 2011. a loenduse andmeil nii vene keelt (194 758 inimest) kui ka inglise keelt (179 153 inimest), vt RL0438: RAHVASTIK VÕÕRKEELTE OSKUSE, VANUSERÜHMA JA ELUKOHA JÄRGI, 31. DETSEMBER 2011.

${ }^{24} \mathrm{p}$ tähendab olulisustõenäosust.
} 
2011. aasta loenduse andmetel oskab ühte võõrkeelt 369532 inimest, kahte võõrkeelt 291961 inimest, kolme võõrkeelt 149611 inimest, nelja võõrkeelt 36111 inimest, viit võõrkeelt 6689 inimest, kuut võõrkeelt 1638, seitset võõrkeelt 417 ja vähemalt kaheksat võõrkeelt 266 inimest. Võõrkeeli ei oska 369027 inimest. Võõrkeelte oskus on teadmata 24182 inimese puhul ning ei saa rakendada 45021 juhul (alla kolmeaastased). ${ }^{25}$

1934. aastal leidus Eestis võõrkeeli oskavaid inimesi vähem kui tänapäeval, suurem osa elanikest ei osanud võõrkeeli. Samas valitses Eesti ühiskonnas võõrkeelte vahel teatav tasakaal: kuigi vene ja saksa keele oskajaid oli teiste keelte oskajatest enam, ei olnud domineerivate võõrkeelte ning teiste võõrkeelte oskajate hulga vahel nõnda suurt erinevust kui tänapäeval. 2000. ja 2011. aastal oli ühiskonnas palju võõrkeeli oskavaid inimesi, samas domineeris selgelt paari võõrkeele oskus. ${ }^{26}$

${ }^{25}$ RL0436: RAHVASTIK EMAKEELE, VÕÕRKEELTE OSKUSE, SOO JA ELUKOHA JÄRGI, 31. DETSEMBER 2011.

${ }^{26}$ 1934. a loenduse andmetel elas Eestis 51 rahvuse esindajaid, tuhande piiri ületasid peale eestlaste veel seitsme rahvuse esindajad: venelased (92 656), sakslased (16 346), rootslased (7641), lätlased (5435), juudid (4434), poolakad (1608) ja soomlased (1088). 2000. a loenduse andmeil elas Eestis 142 rahvusest inimesi, neist 22 rahvust oli esindatud alla 1000 inimesega, 36 rahvust - alla 100 inimesega ja 72 rahvust - alla 10 inimesega. 2011. a andmeil elas Eestis 181 rahvusest inimesi, vt RL0428: RAHVASTIK RAHVUSE, SOO JA ELUKOHA JÄRGI, 31. DETSEMBER 2011. 2000. a loendusel nimetati küll 109 rahvuskeelt, kuid enamikku neist ei osatud ega kasutatud. Kõigis rahvusrühmades, k.a eestlased, oli rahvuskeelt emakeelena (esimese keelena) kõnelejate arv rahvusrühma liikmete koguarvust väiksem. Ainuke erand oli vene keel, mille kõnelejate arv ja osakaal oli suurem kui venelaste arv ja osakaal. 97\% Eesti elanikest rääkis emakeelena või esimese keelena kas eesti või vene keelt. Ülejäänud 107 keele kõnelejad kokku moodustasid u 3\% elanikkonnast. Valdav osa oma rahvuskeelt mittekõnelevaid inimesi oli oma emakeeleoskuse minetanud juba enne Eestisse jõudmist ning siirdunud vene keelele (v.a rootslased ja soomlased, kelle esindajatest oluline osa rääkis esimese keelena eesti keelt). Kuna teiste rahvuste (peale eestlaste ja venelaste) hulgas oli rahvuskeelt emakeelena kõnelevate inimeste osakaal väga väike, siis ei ole rahvuskeelte paljusust ühiskonnaelus eriti märgata olnud. Seega ei olnud emakeeleoskus võrreldes nt 1934. a loenduse andmetega paljudel juhtudel rahvuse määrajaks ega identiteedi sümboliks (Eesti raport 2008: 17; Tender 2009: 15-16). 2011. a loendusel nimetati 157 emakeelt, neist alla 10 kõnelejaga oli 80. 


\section{Murdeoskuse küsimus rahvaloendusel}

2011. aastal võimaldas rahvaloendus esimest korda Eesti rahvaloenduste ajaloos eesti emakeelega Eesti püsielanikel hinnata ja märkida loendusankeeti oma eesti murrete oskust. Pisut alla $15 \%$ nendest nii ka toimis. Kõige enam märgiti Võru murde oskust (87 048 inimest, sh 12549 inimesel Setu murrak), saarte murrete 24520 (sh 1320 inimesel Kihnu murrak) ja Mulgi murde (9698 inimest) oskust ${ }^{27}$. Vaatleme artiklis lähemalt just nende kolme murderühma, põhjaeestilise saarte murde ning lõunaeestiliste Mulgi ja Võru murde oskajaid. Peamine põhjus, miks on valitud just need murded, on asjaolu, et loendusel murdeoskust märkinud püsielanikest valis valdav osa (üle 92\%) just nendesse kolme murderühma arvatud murdeid või murrakuid $^{28}$. Üle kümne aasta tagasi on nendel murdealadel korraldatud ka eesti allkeelte seisundi uuringuid ja tollaseid tulemusi saab loendusandmetega kõrvutades täiendavalt tõlgendada (Eichenbaum, Koreinik 2008). Mida tulemuste puhul tähele panna ja kuidas neid interpreteerida?

Tänapäeva ühiskonda ei iseloomusta enam ammu omaaegsed barjäärid (sunnismaisus, piiratud sotsiaalne mobiilsus), mille tulemusena kohamurded üldse tekkida said. Eesti-sisese rände tõttu on elanikke juurde võitnud viimastel kümnenditel ennekõike keskused, (suured) linnad ja nende tagamaad. Mulgimaa (omaaegne Lõuna-Viljandimaa), saared ja Võrumaa (maakond aastatel 1783-1920) on perifeersed ja osalt just seetõttu säilitanud oma kohamurded. Sestap on huvitav teada, kui suur osa traditsiooniliste murdealade püsielanikest märkis loendusel murdeoskust. Traditsioonilisel Mulgi murdealal, ligikaudu tänapäevase Abja, Halliste, Helme, Hummuli, Karksi, Paistu, Põdrala ja Tarvastu vallas ning Mõisaküla ja Tõrva linnas on püsielanikke kokku 18 444, kellest Mulgi murde oskust märkis pisut vähem kui 16\%. Kõige väiksem oli Mulgi murde oskust märkinud inimeste osakaal Paistu vallas (7,5\%), Mõisaküla linnas (8\%) ja Hummuli vallas (11,7\%). Kõige suurem Mulgi murde oskajate osakaal oli Põdrala vallas (22,8\%). Mulgi murde oskajatest elab vaid pisut üle 30\%

${ }^{27}$ Lisaks märkis 1002 inimest veel oma Lõuna-Eesti murde oskuse. RLE07: EESTI EMAKEELEGA PÜSIELANIKUD MURDEKEELE OSKUSE JA SOO JÄRGI, 31. DETSEMBER 2011. Kõigist Eesti püsielanikest märkis murdeoskuse kümnendik.

${ }^{28}$ Traditsiooniliste murdealade andmete analüüsimisel oleme kasutanud statistikaametist saadud andmeid, loendusankeedi vastuste sagedusi, mille põhjal oleme välja arvutanud jaotused. 
Mulgimaal, ülejäänud aga mujal Eestis. Traditsioonilisel saarte murde alal, mis tänapäeval kattub Hiiu ja Saare maakonna linnade-valdade ning Kihnu vallaga, märkis saarte murde oskust $28,7 \%$ püsielanikest. Saarte murde oskuse märkijate kõige suurem osakaal oli Kihnus $(85,6 \%)$, aga ka Kihelkonna (51\%), Torgu (50,4\%) ja Muhu (47,1\%) vallas. Kõige väiksem saarte murde märkimise osakaal oli Ruhnus $(16,4 \%)$, aga ka Hiiumaal: Kärdlas (15,3\%), Kõrgessaare (17,8\%) ja Käina (17,5\%) vallas. Kõikidest loendusel saarte murde oskust märkinud Eesti püsielanikest elab Saaremaal, Hiiumaal, Muhumaal, Kihnus ja Ruhnus alla poole (47,2\%). Traditsiooniline Võru murde ala asub küll Kagu-Eestis ${ }^{29}$, aga ulatub ka Vene Föderatsiooni territooriumile, kus elab hinnanguliselt 300 seto keele (Setu murraku) kõnelejat (Juhkason jt 2012; vt ka Manakov 2009) ${ }^{30}$. Kuna rahva ja eluruumide loenduse andmed puudutavad vaid Eesti püsielanikke, saame vaadelda 28 tänapäeva linna ja valda ${ }^{31}$. Nende omavalitsuste püsielanikest märkis 59,4\% Võru murde (setu ja võru keele) oskust. Kõige suurem osakaal on Haanja (79,7\%), Misso (78,1\%), Varstu (75,9\%), Mõniste $(73,4 \%)$, Orava $(73,1 \%)$, Meremäe $(73,0 \%)$, Värska $(72,1 \%)$ ja Lasva $(70,8 \%)$ vallas. Kõige väiksem Võru murde oskust märkinute osakaal on aga Valga maakonnas Karula (37,3\%) ja Taheva vallas (41,6\%). Setumaal ja nn vanal Võrumaal elab 41,6\% kõikidest Võru murde oskust märkinud inimestest. See ja eespool toodud osakaal Mulgi ja saarte murrete oskamise kohta väljaspool traditsioonilist murdeala näitab keelevahetuse kõrval ka väljarännet, mis on ilmselt olnud kõigis vaadeldud perifeeriates suur. Näiteks on Tallinn ja Tartu ühed suurimad setu ja võru keele oskajate „diasporaad”, kus keele põlvkondlik ülekanne on traditsioonilise murdealaga võrreldes vaevalisem või lausa võimatu, sest kohalik keeleökoloogia keelekasutust ei toeta. Külli Eichenbaum ja Kadri Koreinik (2008) on võrrelnud kolme põlvkonna sünnikohti ja pakkunud seisundiuuringute põhjal, et erinevalt

${ }^{29}$ Lõunaeesti murret kõneldi veel keelesaartel Lätis ja Venemaal (EMK 2002).

${ }^{30}$ 2001. aasta alguses oli Petseri rajoonis 618 eestlast, sh ilmselt mitte üle 400 seto, mis moodustab u 1,5\% rajooni rahvastikust. 2002. aasta ülevenemaalise rahvaloenduse käigus loendati Petseri rajoonis üksnes 172 eestlast (sh setot), kellest üle poole elasid maal (Manakov 2004).

${ }^{31}$ Antsla, Haanja, Kanepi, Karula, Kõlleste, Laheda, Lasva, Meeksi, Meremäe, Mikitamäe, Misso, Mooste, Mõniste, Orava vald, Põlva linn, Põlva, Rõuge, Räpina, Sõmerpalu, Taheva, Urvaste, Vastseliina, Valgjärve, Varstu, Veriora, Võru vald, Võru linn, Värska vald. 
Saare- ja Võrumaast võib sisseränne Mulgimaale olla olnud palju suurem. Nende hinnangul on Saaremaal põliselanikke 3/4 ja Võrumaal pooled. Karl Pajusalu (1987) on ennustanud Karksi murrakule kiiremat nivelleerumist kui Võru murdele ja Kihnu murrakule. Keelevahetuse põhipõhjuseks peetakse muutusi keelekeskkonnas, mis vähendavad keele funktsionaalsust (Mufwene 2008). Ilmselt on Mulgi murde kiiremas hääbumises osa nii keelekasutust toetava keskkonna puudumisel, mida hästi demonstreerib keele oskajate absoluutne ja suhteline arv, kui ka põhjaeestilise ühis- ja kirjakeele lähedus. Samas on keelevahetus toimumas ka teistel traditsioonilistel murdealadel. Näiteks Võru murdealal torkab silma nooremate elanike ja nooremate keeleoskajate vähesus (joonis 2).

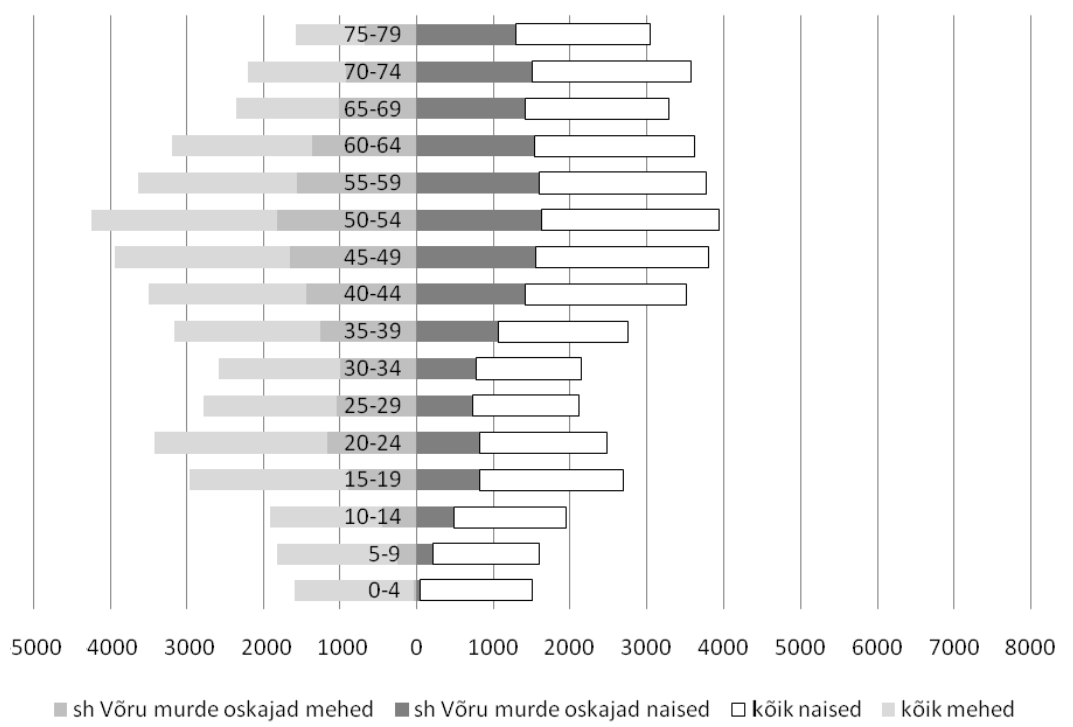

Joonis 2. Võru murdeala püsielanikud ja Võru murde oskajad soo ja vanuse järgi. Murdekeele oskuse andmed esitatakse kolmeaastaste ja vanemate isikute kohta (REL 2011)

Kõige olulisem rahvaloenduse tulemus murrete seisukohast on ootamatult suur kohamurde oskust märkinud püsielanike osakaal ja eelkõige väljaspool traditsioonilist murdeala elavate murdeoskust märkinud inimeste suur osakaal. Ehkki on selge, et traditsioonilise murdealaga võrreldavat keelekeskkonda pole murdealalt väljarännanud inimeste keelekasutust 
toetamas, on viimane tulemus omamoodi keelepoliitiline väljakutse ja nõuab vastuseid järgmistele küsimustele: kas ja kuidas toetada Võru, saarte ja Mulgi murde oskajaid Tallinnas ja Tartus, kas kujunenud olukorras on võimalik rääkida enam piiratud geograafilise kasutusega „konserveerunud” kohamurretest või vastuolulise tähendusega murdekeeltest?

\section{Diskussioon ja kokkuvõte}

Meie kirjutisel on paar rõhutamist väärivat tulemust. Esiteks on Eestis kolmveerandsaja aastaga kasvanud mitut keelt oskavate inimeste osakaal. Kas mitmekeelsete inimeste osakaalu suurenemisega on selle ajaga kasvanud ka Eesti ühiskondlik mitmekeelsus, sellele on keerulisem vastata - arvame, et mitte. Ühiskondlik mitmekeelsus pole ühiskonnas toimetavate indiviidide mitmekeelsuse summa, vaid keelekeskkond, mis struktureerib indiviidide keelelisi valikuid ja interaktsioone (Blommaert jt 2005), st keskkond, mis soodustab suure osa ühiskonnaliikmete mitme keele oskamist ja kasutamist. Rahvaloenduste tulemused näitavad selgelt inglise keele suurenevat osakaalu teiste võõrkeelte seas: inglise keele oskajate osakaal on võrreldes 1934. aastaga 20 korda kasvanud. 80 aastat tagasi domineerinud saksa keele oskajate hulk ühiskonnas on tänaseni suhteliselt stabiilsena püsinud, kuid saksa keel on minetanud dominantkeele staatuse ning 2011. aastal oli Eestis soome keele oskajaid esimest korda rohkem kui saksa keele oskajaid. Rahvaloendustel kogutud võõrkeeleoskuse tulemusi toetavad ja aitavad tõlgendada Euroopa Komisjoni (EK) algatatud keelealased Eurobaromeetri uuringud (arvamusküsitlused) „Eurooplased ja keeled” (2001, 2006, 2012). Need annavad ülevaate keeleoskusest ja keelte õppimisest ning hoiakutest keelte ja tõlkimise suhtes Euroopa Liidus. Näiteks 2012. a uuringu üks küsimus (1a) palus vastajal jätta oma emakeel kõrvale ning nimetada kaks keelt, mis on tema hinnangul isiklikus arengus kõige olulisemad. Kui Euroopa Liidu 27 liikmesriigi keskmise arvamuse järgi pidas isikliku arengu vaatevinklist oluliseks inglise keelt 67\% küsitletuist, siis Eestis 75\%, st Eestis hinnati inglise keele oskust veidi kõrgemalt. Saksa keelt väärtustasid ELis 17\% küsitletuist, kuid Eestis 10\%. Vene keelt tähtsustasid ELis 4\% küsitletuist, kuid Eestis 47\% (Eurobaromeetri uuring „Eurooplased ja keeled”, 2012). Inglise keele domineerimisele ei ole vaja kaugelt põhjendust otsida. Ühe selgituse kohaselt on tegemist kooli mõjuga: võõrkeeleõpe algab juba 
algklassides ning paljudes koolides on inglise keel esimene õpitav võõrkeel. Teise selgituse kohaselt omandavad noored teatava inglise keele oskuse väljaspool kooli, st koolist olenemata. Motivatsioon inglise keelt õppida ja kasutada on väga suur ning õpivõimalused laialdased. Kindlasti aitab inglise keele populaarsusele ja oskusele kaasa seda soodustav (kommunikatiivne, kultuuriline, haridus- ja teadusalane) keskkond ning arvukad kasutusvõimalused (virtuaalvõrgustikud, infotehnoloogilised võimalused), üleüldine inglise keele mõju laienemine, mida Robert Phillipson (1992, 2006) peab keeleliseks imperialismiks. Välisele survele lisaks ei saa täiesti kõrvale jätta Eesti enda mõningast avanemist sisserändajatele. Olles peamiselt väljarändemaa, kus inglise keelt on õpetatud võõrkeelena, on Eestisse elama ja tööle asunud inimesi, kelle jaoks inglise keel on emakeel või teine keel. Küllap on inglise keel Eestis n-ö neutraalne vahendajakeel, mille kaudu suhtlevad eri rahvusrühmad.

Mõtestamist vajab ka murdeoskuse mõõtmise küsimus. Ehkki setu ja võru aktivistid soovisid loendamisel kasutada keeleoskuse mõõtmiseks teistsugust sõnastust (keel versus murre) ja mõõta mh kohalikku (sub-) etnilist identiteeti (mulk, seto, võroke), kasutati loendamisel tuttavaid kohamurrete nimetusi (Kihnu, Mulgi, Saare jt), mitte Eesti murdeuurimisest tuntud traditsioonilist murdeliigendust (murdeliigenduse kohta vt EMK 2002; Pajusalu 2003), mida rakendati tulemuste grupeerimisel ja esitamisel. Küllap on põhjuseks asjaolu, et enamasti koolis omandatud murdeliigendusalased teadmised varieeruvad tublisti. Nõnda väidab Siim Antso oma bakalaureusetöös (2012), et läheduses asuvaid murdealasid suudavad gümnaasiumiõpilased kaardile täpsemini märkida kui kaugemal asuvaid; kõige täpsemini paigutasid (sh ka Pärnu-Jaagupi) õpilased kaardile Võru murde. Kuigi pole selge, kas esineb erinevusi sisserännanud ja teiste õpilaste teadmistes, näitab Antso, et Võru murre on õpilaste jaoks teistest eristuvam. Eristumisel võib olla mitu põhjust, eelkõige murde eripära kogemine kas suhtlussituatsiooni(de)s või meedia kaudu. Teise vastuargumendina võib esitada Pajusalu (2013) väite, et traditsiooniline eesti murrete klassifikatsioon põhineb häälikuliste ja grammatiliste joonte levikuandmetel ega arvesta sõnavara variatiivsust. Kuigi keeleaktivistide eesmärk oli „murdest” märksa prestiižsema termini „keel” kasutamine ning 1998. aasta uuringu andmetel kasutati Võru murdealal keele omanimetusena valdavalt „võro kiil” või „,võru keel” või lihtsalt „,võro” või „,võru”, mitte „Võru murre” (Koreinik, Pajusalu 2007; Eichenbaum, 
Koreinik 2008), arvame, et keelekasutajate arvu selgitamisel pole suurt vahet, kumba mõistet kasutada. Neid vastajaid, kes jätsid mõistet silmas pidades protestiks vastamata, võis olla üksikuid ning üldist tulemust see ei mõjuta.

Teine ja märksa olulisem on küsimus, kas rahvaloenduse kohamurrete tulemused on üldse valiidsed: kas mõõdeti seda, mida sooviti mõõta? Kahtlemata võimaldab küsimus „Kas Te oskate mõnda kohalikku keelekuju, murret või murrakut? Palun nimetage see kohalik keelekuju, murre või murrak, mida Te oskate (kõige paremini) (vastusevariantidega Kihnu, Mulgi, Saare, Setu, Võru, Kodavere, Hiiu, Muu (Märkige))" mitut tõlgendust. Ehkki küsimus sisaldas uudissõna „,keelekuju”, oli erinevalt $\mathrm{CAPI}^{32}$-st veebiankeedi ekraanil alati nähtav ka definitsioon „Kohaliku keelekuju või murde all mõeldakse eesti kirjakeelest erinevat kohalikku keelepruuki, mitte võõrkeeli”. Veidi põhjalikum abitekst, mille nägemiseks tuli lingile klõpsata, oli sama mis loendusjuhendis: „Kohaliku keelekuju või murde all mõeldakse eesti kirjakeelest erinevat kohalikku keelepruuki, mitte võõrkeeli. Niisugust kõnepruuki võidakse nimetada kohalikuks keeleks, murdeks või murrakuks. Kohaliku keelekuju või murde oskajaks loetakse isik, kes saab sellest keelest aru ja suudab ka end väljendada." Abitekst sisaldas keeleoskuse definitsiooni. Tulemuste tõlgendused, et u $15 \%$ püsielanike poolt loenduses märgitud murdeoskuse tulemused võivad peegeldada nii kollektiivset (sub)etnilist identiteeti, retseptiivset keeleoskust või väljarännet keskustesse, aga ka nostalgiat, grupi lojaalsust (kas eraldi või kõik koos), on usutavad. Nende tõlgendusvõimaluste kõrval pakume, et rahvaloenduse tulemuste põhjal on võimalik hinnata potentsiaalsete keelekasutajate arvu. Potentsiaalseteks keelekasutajateks peame nii neid, kes kasutavad mõnd keelt iga päev, kui ka neidki, kes teatud soodsate tingimuste ilmnedes on suutelised mõnd keelt kasutama. Üldiselt toetavad loenduse tulemused varasemaid hinnanguid. Varem on eelnimetatud kohamurrete oskust ja kasutust püütud hinnata vaid murdealade $^{33}$ piires (Eichenbaum 1998; Eichenbaum, Koreinik 2008). Näiteks võru keele (Võru murde) passiivsete ja aktiivsete keelekasutajate arvu on väljarännet arvestades hinnatud vahemikku 50000 - 70 000. Nooremad vanuserühmad hindavad võru keelest arusaamist ja selle rääkimist keskmiselt kehvemaks kui vanemad vanuserühmad, võru keeles lugemist ja

\footnotetext{
${ }^{32}$ Ingl computer-assisted personal interviewing.

${ }^{33}$ Saarte murrete puhul üksnes Saare maakonna elanikkonna hulgas.
} 
eriti kirjutamist on ühtviisi kehvaks pidanud kõik vanuserühmad (Koreinik 2013; Koreinik, Praakli 2013). Arvatavasti on siin tegemist madala prestiižiga ja kõrge prestiižiga keelekuju väljakujunenud kasutusvaldkondadega (diglossia), mille järgi on võru keel ennekõike suuliseks kasutamiseks ning kirjakultuuri ja asjaajamise keeleks on eesti kirjakeel (normikeel).

Rahvaloenduse tulemustest ilmneb, et oluline osa murdekeele mõistjatest elab väljaspool traditsioonilisi murdealasid, mistõttu võib kahtluse alla seada juriidilise termini ,,piirkondlikud erikujud”. Seetõttu võiks mitmekeelsust kirjeldada uute, enam motiveeritud mõistete abil. Hoolimata asjaolust, kas keeled on n-ö omad või võõrad, ametlikud või mitteametlikud, normitud või normimata, võib neid pidada kas domineerivateks (ingl dominant languages) ja mittedomineerivateks keelteks (ingl non-dominant languages). Kuna traditsiooniliste kohamurrete kõnelejate elupaik ei piirdu enam ammu traditsiooniliste murdealadega, siis võiks nii traditsiooniliste kohamurrete, osaliselt standarditud keelevariantide kui ka osa standarditud keelte (nt vähem mainekate võõrkeelte) puhul tarvitada üldmõistet „,mittedomineerivad keeled”, mis ,,viitab antud riigis pruugitavatele keeltele või keelevariantidele, mida ei peeta silmapaistvaks kõnelejate arvu, prestiiži või valitsuses ja/või haridussüsteemis tarvitatud ametliku kasutuse poolest"34 (Benson, Kosonen 2012: 112). Domineeriv keel seevastu võiks olla - erinevalt eespool nimetatud autorite pakutust mitte domineeriva enamuse poolt kasutatud riigikeel, vaid terminit võiks hoopis kasutada mitmuses: „domineerivad keeled”. Eesti dominantkeeled oleksid eesti keel ning valdkonniti ja piirkonniti ka inglise ja vene keel. Selline mõistekasutus kirjeldab hästi kujunenud sotsiolingvistilist situatsiooni ja igapäevapraktikat ning eristab ühtlasi eri mõju- ja kasutusulatusega võõrkeeli. Aeg näitab, kas uued ühiskondlikku mitmekeelsust kirjeldavad mõisted juurduvad.

\footnotetext{
${ }^{34}$ Artikli autorite tõlge.
} 


\section{Kirjandus}

Anderson, Benedict 1991 (1983). Imagined Communities. Chicago: University of Chicago Press.

Anniste jt 2012 = Kristi Anniste, Tiit Tammaru, Enel Pungas, Tiiu Paas. Dynamics of educational differences in emigration from Estonia to the old EU member states. - Trames. Journal of the Humanities and Social Sciences 16 (1), 219-235.

Anniste, Kristi, Tiit Tammaru 2014. Ethnic differences in integration and intentions of return migration: a study of Estonian migrants in Finland. Demographic Research 30 (13), 377-412.

Antso, Siim 2012. Etnodialektoloogiline uurimus õpilaste murdetundmisest. Bakalaureusetöö. Käsikiri Tartu Ülikooli eesti ja üldkeeleteaduse instituudis.

Appadurai, Arjun 2005 (1996). Modernity at Large. Cultural Dimensions of Globalization. University of Minnesota Press.

Appadurai, Arjun 2006. Fear of Small Numbers. An Essay on the Geography of Anger. Durham/London: Duke University Press. http://dx.doi. org/10.1215/9780822387541.

Arel, Dominique 2002a. Demography and politics in the first post-soviet censuses: mistrusted state, contested identities. - Population (English Edition) 57 (6), 801-827. http://dx.doi.org/10.3917/pope.206.0801.

Arel, Dominque 2002b. Language categories in censuses: backward- or forwardlooking. - Census and Identity. The Politics of Race, Ethnicity, and Language in National Censuses. Ed. David I. Kertzer, Dominique Arel. Cambridge: Cambridge University Press, 92-120.

Benson, Carol, Kimmo Kosonen 2012. A critical comparison or languagein-education policy and practice in four southeast Asian countries and Ethiopia. - Multilingual Education and Sustainable Diversity Work. From Periphery to Centre. Ed. Tove Skutnabb-Kangas, Kathleen Heugh. London: Routledge, 111-137.

Blackledge, Adrian 2005. Discourse and Power in a Multilingual World. Philadelphia, PA: John Benjamins. http://dx.doi.org/10.1075/dapsac.15.

Blommaert jt 2005 = Jan Blommaert, James Collins, Stef Slembrouck. Spaces of multilingualism. - Language \& Communication 25 (3), 197-216. http:// dx.doi.org/10.1016/j.langcom.2005.05.002.

Bourdieu, Pierre 1977 (1971). Outline of a Theory of Practice. Cambridge, New York: Cambridge University Press. http://dx.doi.org/10.1017/ CBO9780511812507.

Bourdieu, Pierre 2003 (1994). Praktilised põhjused. Teoteooriast. Tallinn: Tänapäev. 
Dave, Bhavna 2004. Entitlement through numbers. Nationality and language categories in the first post-Soviet census of Kazakhstan. - Nations and Nationalities 10 (4), 439-459.

Dulitšenko, Aleksandr 2004. „Nil mortalibus arduum est!” ehk kui palju keeli suudab inimene ära õppida? - Maailmakeele otsinguil ehk Interlingvistika kõigile. Tartu: Tartu Ülikooli Kirjastus, 25-36.

Eesti raport 2008 = Keelehariduspoliitika ülevaade. Eesti raport. Koost. Made Kirtsi, Birute Klaas, Irene Käosaar, Kristi Mere, Järvi Lipasti, Hele Pärn, Maie Soll, Anastassia Zabrodskaja, Tõnu Tender (komisjoni esimees), Ülle Türk, Jüri Valge, Silvi Vare; retsensendid Martin Ehala, Urmas Sutrop; keeletoimetaja Kersti Kaldma. Tartu: Haridus- ja Teadusministeerium. http://ekn.hm.ee/node/38 (28.02.2014).

Eesti Vabariigi põhiseadus. https://www.riigiteataja.ee/akt/127042011002 (28.02.2014).

Eichenbaum, Külli (toim.) 1998. Ku kavvas Setomaalõ seto rahvast jakkus. Ajaloolise Setomaa põlisasustuse säilimise võimalused. Võro Instituudi uurmistüü Setomaal 1997. aastagal. (= Võro Instituudi toimõtiseq 2.) Võro: Võro Instituut.

Eichenbaum, Külli, Kadri Koreinik 2008. Kuis eläs mulgi, saarõ ja võro kiil? Kohakeelte seisundiuuring Mulgimaal, Saaremaal ja Võrumaal. (= Võro Instituudi toimõndusõq 21.) Võro: Võro Instituut.

ELDIA = European Language Diversity for All. http://www.eldia-project.org (28.02.2014).

EMK 2002 = Karl Pajusalu, Tiit Hennoste, Ellen Niit, Peeter Päll, Jüri Viikberg. Eesti murded ja kohanimed. Toim. Tiit Hennoste. Tallinn: Eesti Keele Sihtasutus.

Eurobaromeetri uuring „Eurooplased ja keeled" 2001, 2006, 2012. http:// europa.eu/rapid/press-release_IP-12-679_et.htm (28.02.2014).

Euroopa keeleoskusuuring 2012. http://uuringud.ekk.edu.ee/est/euroopa-keeleoskusuuring/ (28.02.2014).

Jakobson, Carl Robert 1868. Eestirahva valguse-, pimeduse- ja koiduaeg. Kolm isamaa kõnet, I. http://et.wikisource.org/wiki/Eestirahva_valguse-, pimeduse-_ja_koiduaeg (28.02.2014).

Juhkason jt $\mathbf{2 0 1 2}$ = Grete Juhkason, Andreas Kalkun, Liina Lindström, Helen Plado. Petserimaa setodest ja nende keelest 2010.-2011. aasta välitööde põhjal. - Õdagumeresoomõ piiriq. Läänemeresoome piirid. Finnic borders. [Konverents 27.-29. oktoober 2012, Nakatu, Võrumaa.] Toim. Jüvä Sullõv. (= Võro Instituudi Toimõndusõq 26.) Võro: Võro Instituut, $11-29$.

Jääts, Indrek 2013. LUGEGE MEID ÜLE! Kagu-Eesti etnoregionalistlikud liikumised ja viimane rahvaloendus. - Akadeemia 6, 1077-1110. 
Keeleseadus 1995. http://www.riigiteataja.ee/ert/act.jsp?id=13290329 (28.02.2014).

Keeleseadus 2011. https://www.riigiteataja.ee/akt/123122013040 (28.02.2014).

Kertzer, David, Dominique Arel 2004. Census and Identity. The Politics of Race, Ethnicity, and Language in National Censuses. Cambridge, UK: Cambridge University Press. http://dx.doi.org/10.1017/CBO9780511606045.

Koreinik, Kadri 2013. Võrukeelsus ja mitmekeelsus ELDIA projekti andmete valguses. - Oma Keel 1, 75-83.

Koreinik, Kadri, Karl Pajusalu 2007. Language naming practices and linguistic identity in South-Eastern Estonia. - Language and Identity in the FinnoUgric World. Proceedings of the Fourth International Symposium on Finno-Ugric Languages at the University of Groningen May 17-19, 2006. Ed. Rogier Blokland, Cornelius Hasselblatt. (= Studia Fenno-Ugrica Groningana 4.) Maastricht: Shaker.

Koreinik, Kadri, Kristiina Praakli 2013. Keele kestlikkuse ja kao konstrueerimine poolavalikes diskursustes. - Eesti Rakenduslingvistika Ühingu aastaraamat 9. Toim. Helle Metslang, Margit Langemets, Maria-Maren Sepper. Tallinn: Eesti Rakenduslingvistika Ühing, 131-148. http://dx.doi. org/10.5128/ERYa9.09.

Manakov 2004 = Андрей Г. Манаков. На стыке цивилизаций: тнокультурная география запада России и стран Балтии. Псков: Псковский государственный педагогический институт им. С. М. Кирова. Псковское отделение Русского географического общества.

Manakov 2009 = Андрей Г. Манаков. Динамика численнности сету Печорского района в XX - начале XX века. - Изборск и его округа. Материалы международной научно-практической конференции 2007-2008 гг. Изборск, 40-44.

Mufwene, Salikoko 2008. Language Evolution. Contact, Competition and Change. Continuum International Publishing Group.

Must, Aadu 2000. Eestlaste perekonnaloo allikad. Tartu: Kleio.

Nabhan, Gary P. 2001. Cultural perceptions of ecological interactions: an „endangered people's" contribution to the conservation of biological and linguistic. - On Biocultural Diversity. Linking Language, Knowledge, and the Environment. Ed. Luisa Maffi. Washington \& London: Smithsonian Institution Press, 145-156.

Pajusalu, Karl 1987. Nivelleeruv murre. Karksi verb. - Keel ja Kirjandus 9, $529-543$.

Pajusalu, Karl 2003. Estonian Dialects. - Estonian Language. Ed. Mati Erelt. (= Linguistica Uralica. Supplementary series 1.) Tallinn: Estonian Academy Publishers, 231-272.

Pajusalu, Karl 2013. Eesti keeleala piirid. - Keel ja Kirjandus 3, 210-213. 
Phillipson, Robert 1992. Linguistic Imperialism. Oxford: Oxford University Press.

Phillipson, Robert 2006. Language policy and linguistic imperialism. - An Introduction to Language Policy. Theory and Method. Ed. Thomas Ricento. Malden, MA, USA; Oxford, UK: Blackwell Publishing, 346-361.

Pungas jt 2012 = Enel Pungas, Ott Toomet, Tiit Tammaru, Kristi Anniste. Are better educated migrants returning? Evidence from multi-dimensional education data. - NORFACE Working Papers 18, 1-33.

PRÕK 2011 = Põhikooli riiklik õppekava, lisa 2 (ainevaldkond „Võõrkeeled” (2010)). http://www.oppekava.ee/images/9/92/Lisa2_ainevaldkond_ voorkeeled.pdf (28.02.2014).

Raag, Raimo 2008. Talurahva keelest riigikeeleks. Tartu: Atlex.

Raamdokument 2007 = Euroopa keeleõppe raamdokument. Õppimine, õpetamine ja hindamine. Tartu: Haridus- ja Teadusministeerium. http://www. hm.ee/index.php?044980 (28.02.2014).

Rahvaloendus 1922 = Eesti riikline statistika. Rahva demograafiline koosseis ja korteriolud Eestis. 1922. a. üldrahvalugemise andmed. I, 1924. Tallinn: Riigi Statistika Keskbüroo.

Rahvaloendus $\mathbf{2 0 0 0}=2000$. aasta rahvaloenduse tulemused. II, Kodakondsus, rahvus, emakeel ja võõrkeelte oskus. http://www.stat.ee/20315 (28.02.2014); 2000. aasta rahva ja eluruumide loendus. Üldinfo. http:// www.stat.ee/20351 (28.02.2014); Statistika andmebaas: Rahva ja eluruumide loendus 2000. Rahvus. Emakeel. Võõrkeelte oskus. http://pub.stat. ee/px-web.2001/Database/Rahvaloendus/databasetree.asp (28.02.2014); Isikuleht, küsimus 14. http://www.stat.ee/20371 (28.02.2014).

Rahvaloendus 2011 = Statistika andmebaas: Rahva ja eluruumide loendus 2011. Rahvastiku demograafilised ja etno-kultuurilised näitajad. http://pub.stat. ee/px-web.2001/Database/Rahvaloendus/databasetree.asp (28.02.2014).

Rahvastiku koostis $\mathbf{1 9 3 4}$ = Rahvastiku koostis ja korteriolud. 1. III 1934 rahvaloenduse andmed. II, 1935. Tallinn: Riigi Statistika Keskbüroo.

REL 2011 Isikuankeet = Rahva ja eluruumide loendus 2011. http://www.stat.ee/ public/files/aruandevormid/30001140811.pdf (28.02.2014).

Scott, James C. 1998. Seeing Like a State. How Certain Schemes to Improve the Human Condition Have Failed. Yale Agrarian Studies Series. New Haven: Yale University Press.

Selirand, Jüri, Karl Siilivask 1996. Eesti maast ja rahvast. Muinasajast maailmasõjani. Tallinn: Olion.

Shohamy, Elana, Durk Gorter 2009. Introduction. - Linguistic Landscape: Expanding the Scenery. Ed. Elana Shohamy, Durk Gorter. New York: Routledge, 1-10. 
Siiner jt 2008 = Maarja Siiner, Tõnu Tender, Triin Vihalemm. Piirkondlike keelekujude tunnustamisest Eestis ja Prantsusmaal Euroopa keelepoliitika taustal. - Emakeele Seltsi aastaraamat 53 (2007), 200-221.

Skuttnabb-Kangas, Tove 2002. Why should linguistic diversity be maintained and supported in Europe? Some arguments. - Language Policy Division, Council of Europe, Strasbourg. http://www.coe.int/t/dg4/linguistic/ Source/Skutnabb-KangasEN.pdf (28.02.2014).

Tammaru jt 2010 = Tiit Tammaru, Kaja Kumer-Haukanõmm, Kristi Anniste. Eesti diasporaa kujunemise kolm lainet. - Eestlased ja eesti keel välismaal. Toim. Kristiina Praakli, Jüri Viikberg. Tallinn: Eesti Keele Sihtasutus, 35-57.

Tannberg, Ene, Tõnu Tannberg 1989. Rahvaloenduse algusaastatest Eestis. Kleio. Teaduslik-populaarne ajaloo almanahh 2. Tartu Ülikool, 29-34.

Tender, Tõnu 2008. Mõnda 1934. ja 1995. aasta keeleseadusest: ühist ja erinevat. - Õiguskeel, 154-159. http://www.just.ee/39014 (28.02.2014).

Tender, Tõnu 2009. Mõnda Eesti keelepoliitikast: vähemus- ja regionaalkeeltest. Vene põlisvähemus Eestis ja Euroopas. Tartu-Kolkja, 2.-3.X 2008. Eesti Regionaal- ja Vähemuskeelte Liit. http://www.estblul.ee/ FILES/2008OldBelievers/11-10.02-tender_est.pdf (28.02.2014).

Tender, Tõnu 2010. Mitmekeelsus Eestis Euroopa Liidu mitmekeelsuse ideaali taustal. (= Dissertationes de mediis et communicationibus Universitatis Tartuensis 9.) Tartu: Tartu Ülikooli Kirjastus.

Tiit, Ene-Margit 2011a. Eesti rahvastik. Viis põlvkonda ja kümme loendust. Tallinn: Statistikaamet.

Tiit, Ene-Margit 2011b. Statistika ajaloost. - Eesti Statistika Kvartalikiri 2, 6-31.

Tisliar, Pavol 2013. Ethnicity and the population of Slovakia between 1919 and 1940. - European Researcher 42 (2), 429-436.

Tõnisson, Jaan 1929. Inglise keel esimeseks võorkeeleks meie koolides. Jaan Tõnissoni kõne riigikogus. - Postimees 17. II.

Vahtre, Sulev 1973. Eesti talurahvas hingeloenduste andmeil (1782-1858). Ajaloolis-demograafiline uurimus. Tallinn: Eesti Raamat. 


\title{
Languages and censuses in Estonia
}

\author{
Kadri Koreinik, Tõnu Tender
}

While some census categories are not devised with an academic purpose (Arel 2002), census data include many self-reported variables of languages and national or ethnic identity. Census categories have been influenced by past practices and pre-census politics in most countries involved in enumeration. The paper briefly outlines some ideological and political aspects of censuses and the history of censuses in Estonia. Based on the census data the paper focuses on two issues: 1) what (foreign) languages Estonian residents master and how the share of those languages has changed over the years; 2) what can be concluded from the 2011 enumeration of local varieties. Compared to 1934, the bigger share of Estonian residents has indicated the knowledge of foreign languages in 2011. English has remarkable prominence compared to other language, except Russian, which has gained speakers by immigration. 15\% of permanent residents with Estonian as the mother tongue also claimed the proficiency of Estonian dialects. As the bigger share of speakers of island, Mulgi and Võru dialects reside outside the traditional dialect area, the question arises: whether the term ,dialect" is appropriate after all. Finally we propose two terms - dominant and non-dominant languages borrowed from Benson and Kosonen (2012) for a wider use.

Keywords: census, multilingualism, foreign language, dialect, Estonia

Kadri Koreinik

Võru Instituut

Tartu 48

65609 Võru

eesti ja üldkeeleteaduse instituut

Tartu Ülikool

Jakobi 2

51014 Tartu

kadri.koreinik@ut.ee
Tõnu Tender

Haridus- ja Teadusministeerium

Munga 18

50088 Tartu

eesti ja üldkeeleteaduse instituut Tartu Ülikool

Jakobi 2

51014 Tartu

tonu.tender@hm.ee 